\title{
DAY USE OF NEST SITES BY THE TASMANIAN BETTONG (BETTONGIA GAIMARDI)
}

\author{
by M. Statham and H. L. Statham
}

(with two tables and two text-figures)

\begin{abstract}
Statham, M. \& Statham, H.L., 2002 (31:xii): Day use of nest sites by the Tasmanian bettong (Bettongia gaimardi). Papersand Proceedings of the Royal Society of Tasmania 136: 83-88. https://doi.org/10.26749/rstpp.136.83

ISSN 0080-4703. Tasmanian Institute of Agricultural Research, Mount Pleasant Laboratories, PO Box 46, Kings Meadows, Tasmania 7249, Australia.

A bettong (Bettongia gaimardi) population in the Tom Gibson Reserve, northern Tasmania, was studied for 16 months by trapping and radio-tracking as part of a long-term study of fencing for control of wallabies and the effect on non-target species. Of particular interest was the bettongs' usage of retained bush areas in cultivated paddocks, and the distribution of nest sites. Sixteen of the 26 bettongs trapped were radio-tracked weekly to their daytime nest sites for intervals of nine to 57 weeks. Bettongs occupied between six and 43 different nests; in all, 305 different nests were located. On $23 \%$ of occasions, adult females shared nest sites with furred young at heel; however, adults rarely shared a nest. Breeding apparently occurred at any time of the year and all adult females had a pouch young every time they were examined.
\end{abstract}

Estimates based on minimum convex polygon position of nest sites averaged 14.5 ha for females and 27.7 ha for males. All nest sites were accessible from low understorey corridors; bettongs did not appear to cross open pasture to access apparently similar habitat to that being used. One young male travelled along a bushland corridor for over $4 \mathrm{~km}$ before radio contact was lost.

Key Words: Bettong nest, Bettongia gaimardi.

\section{INTRODUCTION}

The Tasmanian bettong (Bettongia gaimardi), a member of the Potoroidae, was once widespread in southeastern Australia, but now occurs only in Tasmania. Although it is found over much of eastern Tasmania in a wide range of dry sclerophyll forest types, it is most abundant in areas with infertile soils, open undergrowth and extensive mycorrhizal root development (Taylor 1993a). It is strictly nocturnal and rests through the day in a nest of grass and bark (Kershaw 1952, Rose 1986, Taylor 1993b). No long-term studies of the use of nest sites by individual bettongs have previously been carried out.

\section{METHODS}

\section{The Study Area}

The study was carried out at the Tom Gibson Reserve ( $41^{\circ} 46$ ' $\left.\mathrm{S}, 147^{\circ} 19^{\prime} \mathrm{E}\right)$, which is $2.5 \mathrm{~km}$ southwest of Epping Forest in the northern midlands of Tasmania. The study area consists of gently undulating quaternary flats of lateritic gravel, sand and clay. There is a ridge of stony dolerite hills on the southwestern margin, and dolerite outcrops of low hills in the north and west, both in the reserve and on private land outside the reserve. Dry sclerophyll forests and woodland dominated by Eucalyptus amygdalina are the predominant vegetation types. Acacia dealbata regrowth, clumps of Banksia marginata, and several large patches of Spyridium vexilliferum are the main shrub species. Heath species such as Hibbertia spp., Leucopogon collinus, L. virgatus and Lissanthe strigosa dominate the undisturbed lateritic areas, although past excavation for gravel has left much of the lateritic ground bare or slowly regenerating. There are patches of dense bracken (Pteridiun esculentum) on sandy soils. Tussocks of Lomandra longifolia and Lepidosperma longitudinaledominate the wide, shallow gullies. Private land to the northeast and east of the reserve has been cleared for grazing and cropping, with some corridors and patches of natural bush retained (see fig. 1).

\section{Trapping}

Bettongs were live-trapped with Mascot treadle traps, $600 \mathrm{x}$ $300 \times 300 \mathrm{~mm}$ in size, during ten trapping periods of four nights each, over 16 months between July 1997 and October 1998. Trapping was concentrated along a bush and pasture interface to maximise capture of individuals whose nesting ranges might include patches of remnant forest isolated by pasture. At each trapping, about 50 traps were set in three rows parallel to a fire trail on the northeastern boundary of the reserve. The first row of 18 traps was placed next to a fire trail, on the reserve side, with a trap spacing of $100 \mathrm{~m}$ (see fig. 1). The first eight of these traps ran between the track and cleared pasture, while the remaining ten trap sites were adjacent to uncleared private land bordering the reserve. Some of the uncleared land was in a narrow strip. The next two rows were $50 \mathrm{~m}$ and $100 \mathrm{~m}$, respectively, further into the reserve. For the first trapping period, the traps were baited with apple following Statham's (1983) method; subsequently, peanut butter was smeared onto the apple and trap treadle. The traps were thoroughly washed with a steam cleaner after each trapping period.

On first capture, each animal was removed from the trap, bagged, weighed and anaesthetised with zoletil (3 mg $\mathrm{kg}^{-1}$ intramuscular) before an electronic chip (Trovan) was implanted just under the skin between the shoulder blades. The females' pouches were checked and any pouch young measured, with care being taken not to remove them from the nipple, as mothers abandon pouch young if they are separated. Most bettongs weighing at least $1 \mathrm{~kg}$ were fitted with individually identifiable radio collars (Sirtrack, Havelock North, New Zealand, weight 44 g each). 


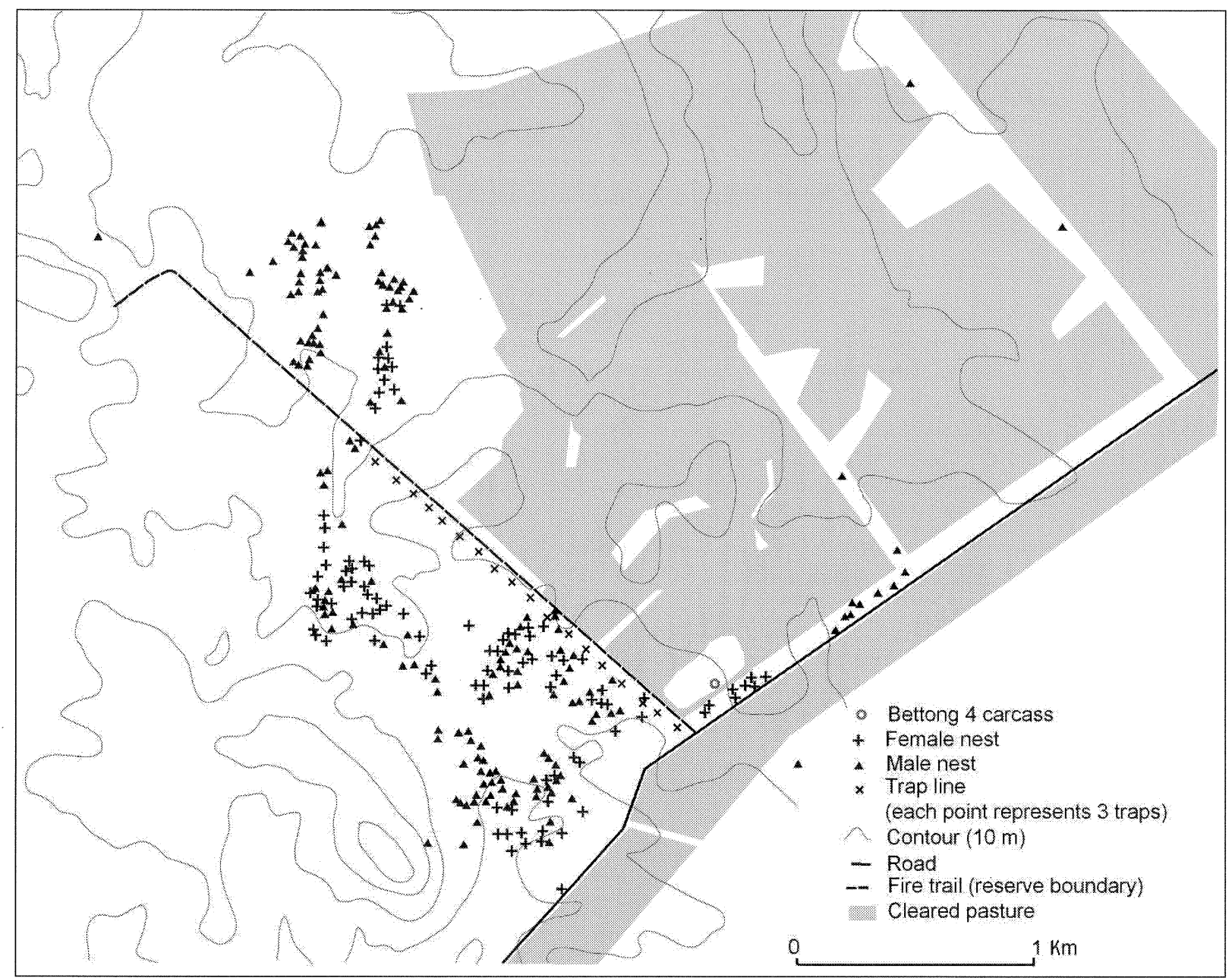

FIG. 1 - Trap and nest sites.

At subsequent capture, individuals were identified, collars were checked, body weights recorded and pouch young measured. Radio collars were removed at the end of the study and the animals released in situ.

\section{Radio Tracking}

Radio-collared bettongs were located at their nest sites during the day, usually once a week, for 57 weeks. Tracking was generally done by two people on foot using a hand-held, three-element Yagi aerial. Each animal was located and its nest site described and marked by a numbered tape. The nest's location was recorded with a GPS receiver. Sixteen different bettongs (six females and ten males) were radiotracked for intervals ranging from nine to 57 weeks (table 1).

\section{Mapping}

A GPS receiver (Trimble GeoExplorer $\mathrm{II}^{\circledR}$ ) was used to map tracks, fences and other features, which were then plotted with bettong trapping and radio-tracking data on a digitised 1:25000 scale base map, using Arcview software. Nest-range sizes were calculated as minimum convex polygons, i.e., the minimum area that included all recorded nests.

\section{RESULTS}

\section{Trapping}

A total of 26 bettongs - 18 males and eight females - were captured. There were 76 male captures and recaptures, ranging from one to 11 per individual, and 40 female captures and recaptures, ranging from one to 12 per individual. The total number of trapping nights was 1380 , with a trapping success rate of $8.4 \%$. No bettongs were captured during the first trapping period, when only apple was used as bait, but at least one animal was captured in all subsequent trapping periods when peanut butter was added to both the bait and the trap treadle plate. They usually ate all the peanut butter and rarely touched the apple.

Other species were occasionally captured: Tasmanian devil (Sarcophilis harrisiz), spotted-tail quoll (Dasyurus maculatus), Tasmanian pademelon (Thylogale billardierii) and black currawong (Strepera fuliginosa). Common brushtail possums (Trichosurus vulpecula) were captured far more frequently than bettongs, with up to 28 a night, while the highest number of bettongs caught in a night was six. (None of the possums was identified or weighed.) The effect of the high trapping rate of possums on numbers of bettongs trapped is unknown. Bettongs were active at night earlier than possums and therefore had access to the traps, but later in the night the number of traps occupied by possums would have reduced those available to bettongs. 
Weights of independently trapped bettongs ranged from 0.9 to $2.2 \mathrm{~kg}$. Most independent males weighed between 1.6 and $2.0 \mathrm{~kg}$. All independent females weighed between 1.6 and $2.3 \mathrm{~kg}$, with some weight, particularly for the heavier ones, attributable to pouch young. It was not possible to accurately record the weight of lactating females because the young, unless fully furred, were usually attached to a nipple.

\section{Nest Sites}

In all, 305 different nests were located. Most were recorded as being used by one bettong on one occasion. Individuals returned to a nest they had previously used on $11 \%$ of occasions and used a nest previously used by a different bettong on $4 \%$ of occasions. Individual nests were rarely found to be used more than twice during the study, although one nest was recorded as used on five occasions. The time interval between recorded use of a particular nest varied between one week and 10 months, with two to three months being the most usual. Individuals used between six and 43 different nests during the study. Concurrent use of nests occurred mainly when furred young were still accompanying their mothers.

The six adult females radio-tracked to their nests were accompanied by a furred young at heel on an average of $23 \%$ of occasions (range $0-44 \%$ between individual females). If flushed out of the nest, the adult female always left the nest several seconds before her young, which hopped off in a completely different direction. On five occasions, two adult bettongs left a single nest, and on one of these a young at heel also emerged. Only one of the two adults was radio-collared on each occasion and hence the sex of the uncollared one is unknown.

The nests were always on the ground and usually in a slight depression. They mostly consisted of a small tunnel of grass, bark or other nesting material built under fallen limbs and litter, in tussocks of Lomandra longifolia or Lepidosperma longitudinale, under very low shrubs such as Hibbertia spp. and Leucopogon spp. or a combination of these conditions. Each nest was very well camouflaged and was found only when the observer was within one to two metres of the bettong being radio-tracked.

All the nest sites were in dry sclerophyll forest or woodland with undisturbed understorey, within the main block of uncleared land, either in the Tom Gibson Reserve or immediately adjacent in private property. The only evidence of movements out of this area were nest sites found in strips of undisturbed forest. An exception was a nest located across the road, used by a male, which could have been accessed by travelling in undisturbed forest or along a shelter-belt except when actually crossing the road (fig. 1). No nest sites or evidence of digging was found in islands of apparently similar remnant forest separated by cleared land, even though the distance was less than 30 metres. For several months during the tracking period the cleared land was fallow, with a soft, friable surface, but no bettong footprints were found on the strip next to the fire trail.

\section{Nesting Range Estimates and Movement}

The nest ranges, or area covered by daytime nesting sites, were calculated from those individuals for which the estimates of maximum nesting range appeared to have been reached (additional data did not increase the nest range) (table 1). These averaged $14.5 \pm 9.2$ ha for females and $27.7 \pm 20.4$ for males.

The ranges of individual females rarely overlapped at a particular point in time, and the nests of each female were closer together than the males' nests. However, when a female died, another would establish in her area. For example, after female number 1 died, number 24 was trapped and tracked in her former range. Male 3 occupied a larger range, overlapping those of both females, throughout the entire study (fig. 2).

The smaller range size for females is also illustrated by figure 2, which shows overlapping trap sites and nest sites of four bettongs (males 5, 7 and 11, and female 17). These four bettongs all moved outside the reserve but stayed within the one block of undisturbed habitat. They spent most of their time outside the reserve, but were readily captured in traps located in the reserve outside their known nesting range.

Only two individuals regularly nested away from the core forest block. These individuals, mother and son (4 and 14) moved along the 40-50 m-wide bush corridor retained to the northeast of the reserve and adjacent to the road (fig. 1). Female number 4 was found dead in an island of bush surrounded by paddock. This was the only time an animal was tracked in a location that required it to cross bare paddock. Soon after, the young male dispersed via bush corridors and was last located $4.5 \mathrm{~km}$ from his earlier nest sites (fig. 1).

\section{Breeding}

Information on bettong breeding was obtained from both tracking and trapping data (table 2). Breeding apparently occurred at any time of the year; all adult females had a pouch young every time they were examined. Individuals often had a small pouch young and another fully furred young at heel. The latter were occasionally trapped with their mother, but were more often flushed out of the nest during day tracking.

\section{DISCUSSION}

Previous studies on the movement of the Tasmanian bettong have indicated home ranges of $50.1 \pm 10.5$ ha for females and $65.3 \pm 19.0$ for males (Taylor 1993a) and approximately 100 ha for males (Johnson 1978, Mooney \& Johnson 1979). As these studies included day nest sites and night tracking data, the ranges are greater than in our study, which was restricted to nesting ranges.

In general, the bettongs were trapped near their nest home ranges. Bettongs 5, 7, 11 and 17 were atypical in that they were trapped at a distance from their known nest ranges (fig. 2). These bettongs conform with a report that bettongs may travel up to $2 \mathrm{~km}$ to and from known feeding areas in a given night (Mooney $\&$ Johnson 1979). This was emphasised by the fact that we were unable to trap these 
TABLE 1

Radio-tracking data: number of times captured, number of weeks tracked, total number of radio fixes, number of different nests, number of fixes to achieve maximum nesting range, and fate of 16 bettongs radio tracked. The mean nest range for males was $27.7 \pm 20.4$, and for females $14.5 \pm 9.2 \mathrm{ha}$.

\begin{tabular}{lcccccccl}
\hline No. & Sex & $\begin{array}{c}\text { Captures } \\
(n)\end{array}$ & $\begin{array}{c}\text { Weeks } \\
\text { tracked } \\
(n)\end{array}$ & $\begin{array}{c}\text { Radio } \\
\text { fixes* }\end{array}$ & $\begin{array}{c}\text { Diff. } \\
\text { nests } \\
(n)\end{array}$ & $\begin{array}{c}\text { Fixes for } \\
\text { max. nest } \\
\text { range }(n)\end{array}$ & $\begin{array}{c}\text { Nest } \\
\text { range } \\
\text { (ha) }\end{array}$ & \multicolumn{1}{c}{ Fate } \\
\hline 1 & $\mathrm{~F}$ & 10 & 47 & 35 & 31 & 31 & 14 & Eaten, skeleton found near collar \\
2 & $\mathrm{~F}$ & 12 & 57 & 43 & 38 & 39 & 12 & $\begin{array}{l}\text { Released at end of study } \\
\text { Released at end of study }\end{array}$ \\
3 & $\mathrm{M}$ & 11 & 57 & 43 & 36 & 31 & 29 & Found dead, suspect Tiger Quoll \\
5 & $\mathrm{~F}$ & 8 & 49 & 36 & 29 & 25 & 27 & Lost signal February 98 \\
7 & $\mathrm{M}$ & 1 & 27 & 24 & 20 & 14 & 20 & Released at end of study \\
8 & $\mathrm{M}$ & 9 & 56 & 30 & 28 & 25 & 22 & Lost signal March 98 \\
9 & $\mathrm{M}$ & 7 & 31 & 23 & 18 & 22 & 72 & Released at end of study \\
10 & $\mathrm{M}$ & 6 & 56 & 34 & 32 & 32 & 23 & Collar recovered, no bettong, March 98 \\
11 & $\mathrm{M}$ & 4 & 25 & 10 & 10 & 9 & 9 & Released at end of study \\
16 & $\mathrm{M}$ & 7 & 56 & 28 & 18 & 23 & 19 & Released at end of study \\
17 & 7 & 28 & 13 & 7 & 13 & - & Released at end of study \\
19 & $\mathrm{~F}$ & 4 & 20 & 16 & 15 & 11 & 5 & Lost signal June 98 \\
21 & $\mathrm{M}$ & 3 & 9 & 6 & 6 & 6 & - & Released at end of study \\
23 & $\mathrm{~F}$ & 1 & 20 & 13 & 13 & 13 & - & Lost signal September 98 \\
24 & $\mathrm{M}$ & 4 & 14 & 10 & 8 & 10 & - & Released at end of study \\
\hline
\end{tabular}

* Equates to the total number of nests found.

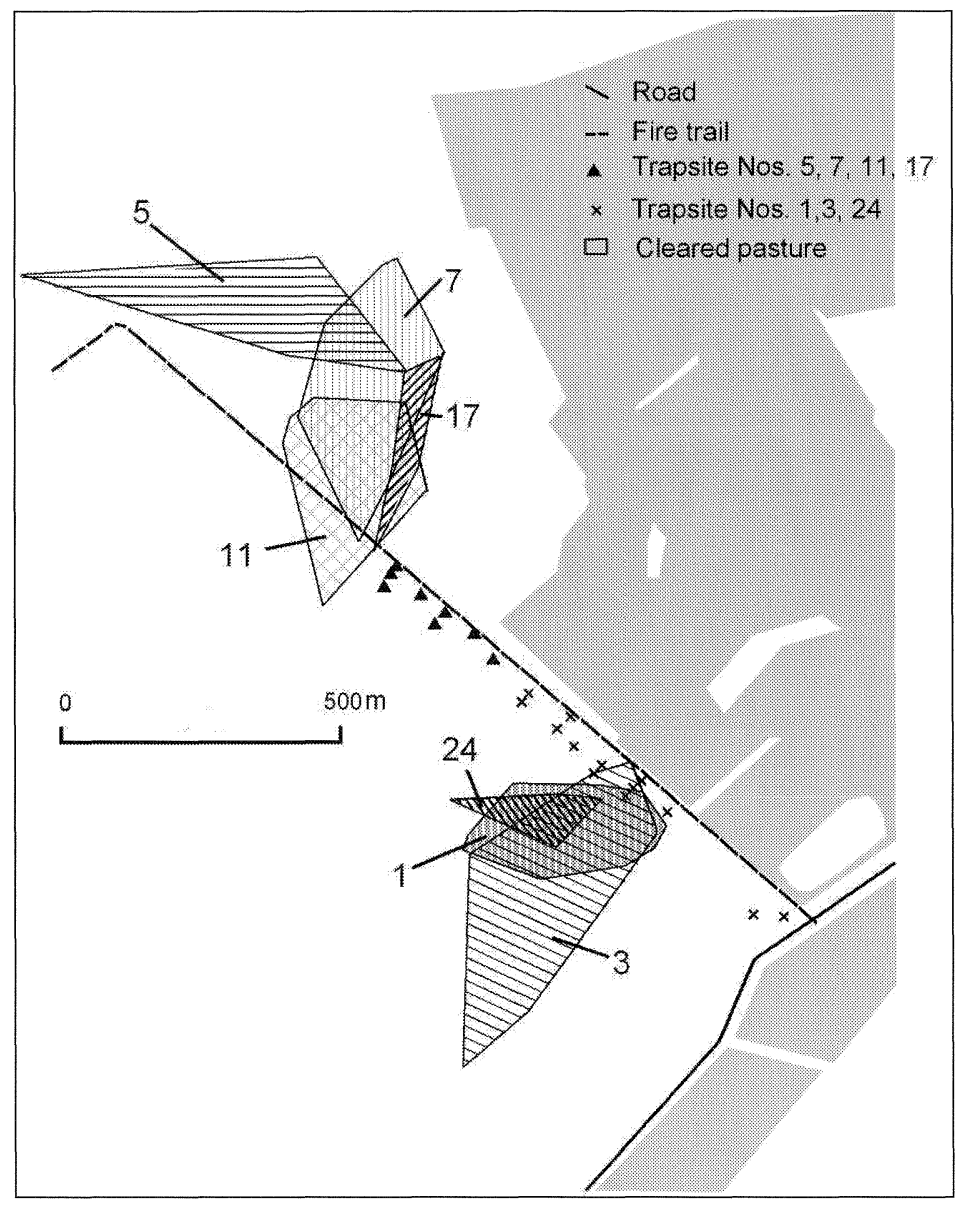

FIG. 2 - Nest range and trap sites of bettongs $1,3,5,7,11,17$ and 24 . 
TABLE 2

Bettong breeding: female bettongs captured during the study and details of small pouch young and furred young at heel from trapping and tracking data

\begin{tabular}{|c|c|c|c|}
\hline $\begin{array}{l}\text { Female } \\
\text { no. }\end{array}$ & Date & $\begin{array}{l}\text { Pouch young } \\
\mathrm{h}+\mathrm{b}(\mathrm{mm})^{\dagger}\end{array}$ & $\begin{array}{c}\text { Furred young trapped with mother or flushed out of nest } \\
\text { when mother was tracked }\end{array}$ \\
\hline 1 & Aug 97 & 20 & \\
\hline * & Aug-Sept 97 & & $\begin{array}{l}\text { One (unidentified) flushed out several times; presumably male \# 6, which } \\
\text { was never collared. }\end{array}$ \\
\hline \multirow[t]{3}{*}{ * } & Nov 97-Jan 98 & & One (unidentified) flushed out, too small to be $\# 6$. \\
\hline & Dec 97 & 50 & \\
\hline & Apr 98 & 50 & \\
\hline * & Apr-June 98 & & Male $22^{\dagger}$ flushed out with mother. \\
\hline \multirow[t]{2}{*}{2} & Aug 97 & 60 & \\
\hline & Dec 97 & + & Furless, not measured. \\
\hline \multirow[t]{3}{*}{ * } & Late Jan-Mar 98 & & Female $15^{\dagger}$ flushed out with mother. \\
\hline & Feb 98 & 15 & Female $15^{\dagger}$ and small pouch young trapped with mother. \\
\hline & Mar 98 & 70 & \\
\hline \multirow[t]{2}{*}{ * } & May-early Jun 98 & & Furred young flushed out with mother. \\
\hline & May 98 & 20 & \\
\hline \multirow[t]{2}{*}{ * } & Aug 98-Sept 98 & & Furred young flushed out with mother. \\
\hline & Oct 98 & 20 & \\
\hline 4 & Aug 97 & 90 & \\
\hline \multirow[t]{3}{*}{ * } & Dec 97 & & Male $12^{\dagger}$ trapped with mother. \\
\hline & Feb 98 & 50 & \\
\hline & Apr 98 & 20 & \\
\hline \multirow[t]{2}{*}{ * } & Apr-Jun 98 & & Male $23^{\dagger}$ flushed out with mother. \\
\hline & May 98 & 80 & Male $23^{\dagger}(1.06 \mathrm{~kg})$ trapped with mother and small pouch young. \\
\hline \multirow[t]{3}{*}{$17^{*}$} & Apr 98 & & Female $18^{\dagger}(0.25 \mathrm{~kg})$ trapped with mother. \\
\hline & May 98 & 50 & \\
\hline & July 98 & 20 & \\
\hline \multirow[t]{2}{*}{ * } & Aug-Oct 98 & & Female $18^{\dagger}$ flushed out with mother. \\
\hline & Oct 98 & + & \\
\hline 21 & May 98 & 50 & \\
\hline \multirow[t]{2}{*}{$*$} & Aug-Sept 98 & & Furred young flushed out with mother. \\
\hline & Oct 98 & 50 & \\
\hline \multirow[t]{2}{*}{24} & July 98 & + & Female $(0.65 \mathrm{~kg})$ died in captivity. \\
\hline & Oct 98 & 50 & \\
\hline
\end{tabular}

${ }^{\dagger}$ Length of head and body in millimetres.

* Observations from radio-tracking; pouch not examined (even if trapped).

four bettongs in their known nesting ranges when trying to replace collars transmitting weak signals. Our data conform with those for other Macropodoidea, in that males had larger home ranges than females (Croft 1989).

Reproduction in this population was similar to that described in a captive population (Rose 1982), with births in all months of the year. After a pouch life of 105 days, the young is replaced by a foetus conceived at a previous postpartum mating (Rose 1982). This allows more than one young to be raised each year.

The use of the 40-50 m-wide bush corridor by two individuals indicates the importance of retaining such strips of natural vegetation for native animals such as the bettong. These corridors reduce the chance of predation when young are dispersing, and allow interaction between otherwise isolated populations, enhancing the genetic variability necessary for long-term species viability.

These data are important to consider when planning wallaby exclusion fencing to minimise effects on other species. Placement of fence lines along pasture and bush interfaces should have little effect on bettong movement, providing "corridor" areas are not closed off. Maintenance of access through bush corridors, and the development of suitably vegetated corridors between areas of remnant forest, will assist in the dispersal of bettongs and maintenance of populations.

\section{ACKNOWLEDGEMENTS}

Funding for this project was provided by the National Feral Animal Control Program, and the Tasmanian Institute of Agricultural Research. Sarah Munks, Ben Sullivan, Randy Rose and Gary King provided valuable comments on drafts of this paper. The research was carried out under National Parks and Wildlife Permit FA96286, and with approval of the Tasmanian Department of Primary Industries, Water and Environment Ethics Committee. 


\section{REFERENCES}

Croft, D.B., 1989: Social organisation of the Macropodoidea. In Grigg, G., Jarman, P. \& Hume, I. (Eds): Kangaroos, Wallabies and Rat-kangaroos. Surrey Beatty \& Sons, Sydney: 502-525.

Johnson, K.A., 1978: Methods for the census of wallaby and possum in Tasmania. National Parks and Wildlife Technical Report.

KerShaw, R.C., 1952: Notes on marsupials at the Tamar river, Tasmania. Victorian Naturalist 69: 102-105.

Mooney, N.J. \& Johnson, K.A., 1979: Methods for the census of wallaby and possum in Tasmania. Tasmanian National Parks and Wildlife Service Technical Report.

Rose, R.W., 1982: Tasmanian bettong Bettongia gaimardi: maintenance and breeding in captivity. In Evans, D.D. (Ed.): The Management of Australian Mammals in Captivity. Zoological Board of Victoria: 108-110.
Rose, R.W., 1986: The habitat, distribution and conservation status of the Tasmanian bettong, Bettongia gaimardi (Desmarest). Australian Wildlife Research 13: 1-6.

STATHAM, H.L., 1983: Browsing damage in Tasmanian forest areas and effects of 1080 poisoning. Forestry Commission Tasmania Bulletin 7.

TAYLOR, R.J., 1993a: Home range, nest use and activity of the Tasmanian bettong, Bettongia gaimardi. Wildlife Research 20: 87-95.

TAYLOR, R.J., 1993b: Habitat requirements of the Tasmanian bettong, (Bettongia gaimardi), a mycophagous marsupial. Wildlife Research 20: 699-710.

(accepted 29 July 2002) 